\title{
PARTICIPATION OF GREEN ENVIRONMENTAL GROUP AND ULUR-ULUR LOCAL WISDOM ON BURET LAKE ECOTOURISM MANAGEMENT IN KARST AREA OF TULUNGAGUNG, INDONESIA
}

\author{
Elya KURNIAWATI* \\ Universitas Negeri Malang, Faculty of Social Science, Sociology Department Malang, Indonesia, e-mail: elya.kurniawati.fis@um.ac.id \\ SUMARMI \\ Universitas Negeri Malang, Faculty of Social Science, Geography Department Malang, Indonesia, e-mail: sumarmi.fis@um.ac.id \\ Muhammad ALIMAN \\ Universitas Negeri Malang, Faculty of Social Science, Geography Department Malang, Indonesia, e-mail: alviageo@gmail.com
}

\begin{abstract}
Citation: Kurniawati, E., Sumarmi, \& Aliman, M. (2020). PARTICIPATION OF GREEN ENVIRONMENTAL GROUP AND ULUR-ULUR LOCAL WISDOM ON BURET LAKE ECOTOURISM MANAGEMENT IN KARST AREA OF TULUNGAGUNG, INDONESIA. GeoJournal of Tourism and Geosites, 30(2spl), 889-895. https://doi.org/10.30892/gtg.302spl15-519
\end{abstract}

\begin{abstract}
Management of karst areas as attractive tourist spots is indeed very promising. Community participation is needed in managing tourist attractions. This research aims to determine: (1) The condition of Buret Lake tourism in the Tulungagung karst area (2) The participation of Green Environmental Group in the management of Buret Lake tourism (3) The existence of Ulur-ulur local wisdom supports the development of Buret Lake tourism. The approach used in this research was qualitative. Data collection was carried out by using observation, in-depth interviews, and documentation studies. The results showed that Buret Lake tourism is a very beautiful and unique karst area whose water source is able to irrigate the residents' fields in 4 villages continuously. The participation of the Green Environmental Group is very instrumental in managing tourist attractions and preserving the Buret Lake. The preservation of the Ulur-ulur ceremony procession which is carried out every year strongly supports the management of the Buret Lake tourism. Therefore, preservation of the environment and local wisdom in Tulungagung needs to be carried out sustainably.
\end{abstract}

Key words: Green Environmental Group, Local Wisdom, Tourism Management

\section{INTRODUCTION}

Nowadays, the existence of karst areas in Indonesia is considered to have very strategic values. Apart from covering almost $20 \%$ of the total area in Indonesia, karst has potential that is not only unique but also very rich, both on biological and non-biological natural resources (Adji, 2010). The unique phenomenon of karst surface, the underground system and river on karst subsurface is an interesting object to study. Another interesting topic to study was the socio-economic conditions of the people who live in it which are also unique because they can survive in a very deep water table condition, and they can only get water from caves and springs. Other natural resources that can be studied are the diversity of typical flora and fauna such as swallows and bats (von Hirschheydt et al., 2020).

The strategic values aimed are values other than being an area also as a supplier and reservoir of water for domestic needs. The need for water is very high for people who live around karst areas that find it difficult to get water, especially during the dry seas on (Arifin, 2018). The United Nations estimate that water supplies for around 25\% of the world's population come from karst water sources (Laksamana, 2005). Karst also has natural resources that can be used to increase the country's foreign exchange, such as tourism and mining of minerals. Some experts define karst as a term for limestone rocks with rare surface drainage, thin soil solum in a few places with clos ed basins (Dolin) and also as underground drainage (Adji, 2010; Blatnik et al., 2020). Another researcher describes karst as a form of land that has specific hydrological characteristics caused by limestone that dissolves easily and has good porosity (Fatin, 2020). The use of geopark areas, including karst areas, has the potential to help rural development and have an impact on reducing unemployment and also to be able to improve the economy of local communities (Farsani et al., 2011; Garidzirai and Pasara, 2020).

Tulungagung is one of the karst areas in Indonesia. The land consists of 1,500 $\mathrm{km}^{2}$ of limestone with Endo and Exsokarst potential, specifically, with endokarst potential in the form of caves, and there are nearly hundreds of caves. Of the many caves in the Tulungagung regency, 16 areas have been identified and mapped (source from: HIKESPI Jogjakarta: 11 caves, MAPALA HIMALAYA STAIN Tulungagung: 5 caves) with varied types of caves from fossil (dry) caves to caves with a potential underground flow (Laksamana, 2005).

The springs can come from any surface of the earth such as hills, lowlands and foothills including karst, but these springs must be maintained (Arifin, 2018; Blatnik et al., 2020). The cave border is a karst formation that must be protected. The local protection on this cave is to prohibit construction activities around the border, damage the decoration in the cave (stalactite, stalagmite, flowstone and others), and pollute the underground rivers. The next border that must be protected is the spring border. The presence of springs must be preserved (Sumarmi, 2018). The community local wisdom has been proven in protecting forests, water resources and its ecosystems. Local wisdom is the knowledge, perspective, and the strategy of the community to face their life problems, and it passed down from generation to generation and integrated into the customs and norms of the community (Lestawi and Bunga, 2020; Putri et al., 2018). Many researchers have studied the role of local wisdom in the conservation of forests and its ecosystems, including water resources. One of them is the local wisdom of the Tengger people in East Java Province, Indonesia, in the forest conservation (Sumarmi, 2018). Many researchers have studied the role of local wisdom in the conservation of forests and its ecosystems, including water resources. Conservation of indigenous forests by Sa sak people in Lombok, Bali Aga people in Bali Province and Minangkabau people in West Sumatra Province, Indonesia (Mutia et al., 2019). Another local wisdom is from the Krui community in Lampung, Indonesia in conserving the Damar tree forest (Istiawati et al., 2020). Also, there are local wisdom studies in South America seven studies, North America seven studies, Africa seven studies, Europe three studies, and Australia two studies have proven that local wisdom has an important role in forest conservation (Joa et al., 2018). Moreover, some research involving 
local communities in tourism management has been carried out, including management of tourism by local communities in Baluran National Park, Indonesia (Purnomo et al., 2020), structural and non-structural mitigation on cultural tourism of local communities in the Segenter Village, Lombok, Indonesia (Wahyuningtyas et al., 2019). Previous research still explores local wisdom and the role of the community in the hill areas of tropical rain forests and areas with high rainfall. However, the uniqueness of this research is the study of ecotourism management by community groups and the role of local wisdom in the Karst area with moderate rainfall in forest conservation and water resources.

\section{LITERATURE REVIEW \& THEORETICAL FRAMEWORK}

Tourism is an individual or group movement activity from one place to another in order to get entertainment (Fang, 2020). In Indonesia, sustainable tourism is developed based on local culture aimed to improve economic, social and environmental conservation (Firdaus et al., 2019). Beside smooth transportation, one of the supports for the development of tourism in an area is the existence of hotels. This existence can provide support for the growth of the local economy, increase employment, provide opportunities for small entrepreneurs, also provide taxes for the region (Dwyer, 2015). It is aligned with the goal of sustainable development, which is to encourage development, especially in reducing unemployment and poverty (Gasper et al., 2019).

Tourism has become a commodity that can help the economies of many countries, especially in developing countries. Nowadays, tourism is developed by producing innovative products, so it becomes an attractive factor for tourists (Nella and Christou, 2016). The innovative products are integrating natural tourism with local cultural elements supported by large amount of data (Huo and Wang, 2020). Tourism that developed based on nature and local culture provides benefits, such as creating jobs for the community around attractions, increasing public awareness in protecting attractions, maintaining local wisdom, becoming a brand of the local community, increasing local taxes and increasing cooperation (Fang, 2020). Nature tourism is tourism with particular interest. Many tourists arrive at natural attractions based on their reputation and high ecological diversity. Tourist activities, either individually or in groups, aim to enjoy the diversity of flora, fauna and nature are called ecotourism (Kiper, 2013). Ecotourism is related to the management of natural resources and activities to enjoy nature that provide economic and social benefits for local communities (Purnomo et al., 2020). Ecotourism emphasizes environmental conservation, increases community welfare and involves the education component (Senigaglia et al., 2020). Ecotourism provides the tourist for more experiences because it consists of many types of entertainment. The tourist attractions found in ecotourism, such as observing rare flora and wild fauna, exploring nature or climbing mountains, also river tourism. Then the cultural tourism from the local community obtained from tourist visits such as handicrafts, traditional dances, and performing arts (Fang, 2020).

At present, the Indonesian government through the ministry of tourism and creative economy has prioritized ten new destinations. The investment budgeted high to develop those destinations. One of the new destinations that become priorities is National Park of Bromo Tengger Semeru in East Java. The distribution of ten new priority destinations in Indonesia follows in Figure 1. Development of the new priority destinations in Indonesia is expected to give benefit to surrounding tourism objects. The influence of the main destination is expected to rise the community's economy around supporting tourist attraction from the main destination (Garidzirai and Pasara, 2020; Poudyal et al., 2020). As a new main destination National Park of Bromo Tengger Semeru (number 8), has one supporting tourist attractions which is Buret Lake ecotourism. The location of National Park of Bromo Tengger Semeru with Buret Lake is about $150 \mathrm{~km}$ or can be reached by driving for 4 hours. Buret Lake ecotourism is unique compared to other lakes in Indonesia. Buret Lake is a lake in a karst area whose water never dries. The lake is not very wide, but it is very deep. Besides, around the ecotourism of Buret Lake, there are also many distinctive flora and fauna. The most beautiful thing on Buret Lake is the turquoise blue water, and this colour only occurs in certain months.

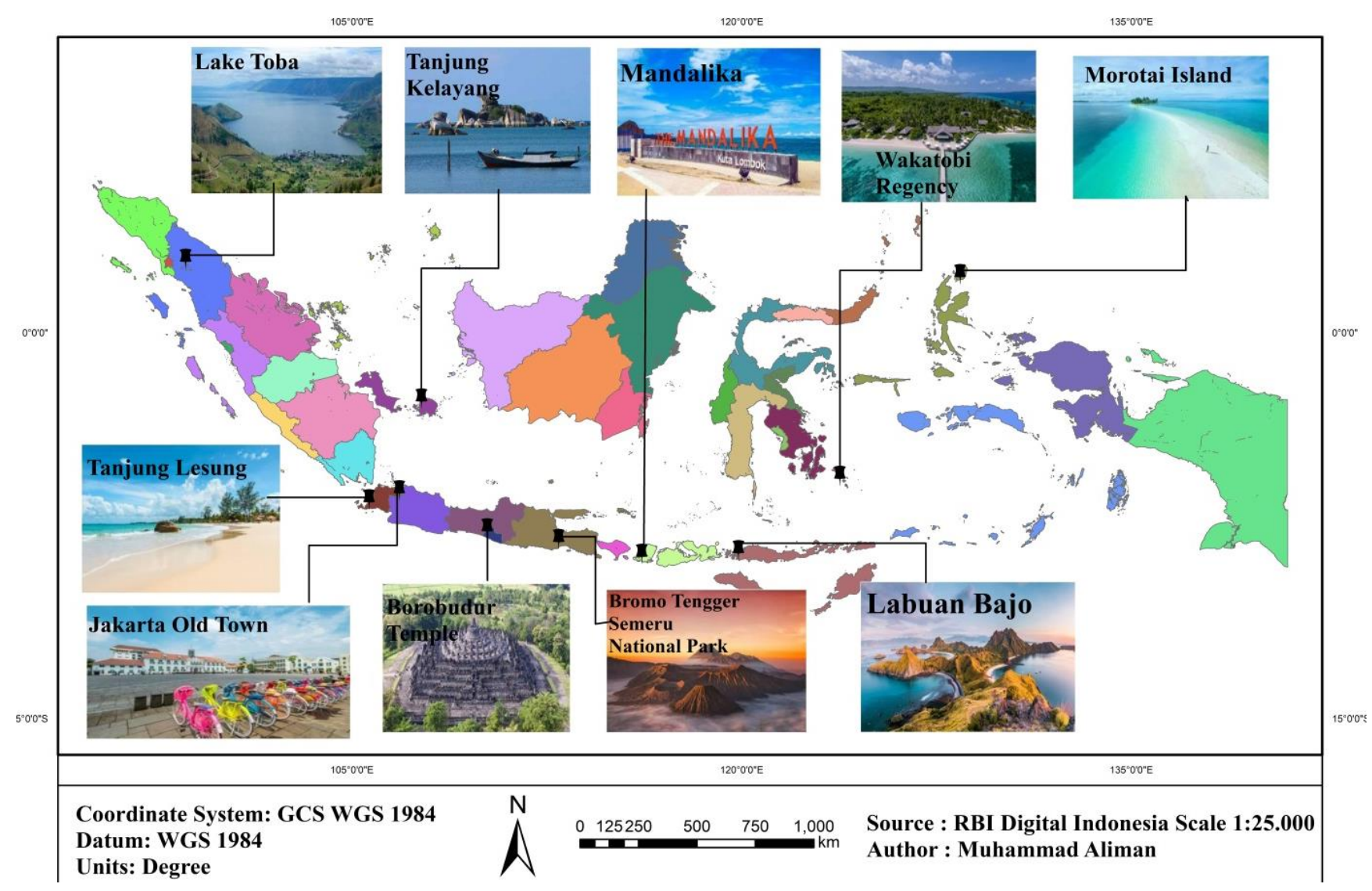

Figure 1. Ten Priorities for New Travel Destinations in Indonesia 


\section{METHODS}

\section{Population and Participants}

Buret Lake is located in Sawo Village, Campur Darat District, Tulungagung Regency, East Java Province, Indonesia. This qualitative research aims to identify the participation of the Green Environmental Group and Ulur-Ulur local wisdom in Tulungagung in preserving the Buret Lake. The population in this study was the community who lived around Buret Lake. The informants were selected based on their indepth knowledge and direct involvement in the management of Lake Buret and the Ulur-Ulur Tradition. The primary data sources in this study were the green environment group, the chairperson of Indigenous Peoples, and the inhabitants around Buret Lake who still preserve Ulur-Ulur tradition. Based on the systematic of informants selection, this study used a purposive sampling method because researchers can choose the informants who understand the condition of Buret Lake and Ulur-Ulur tradition (Suri, 2011). The following is the location of Buret Lake as showed on Figure 2.

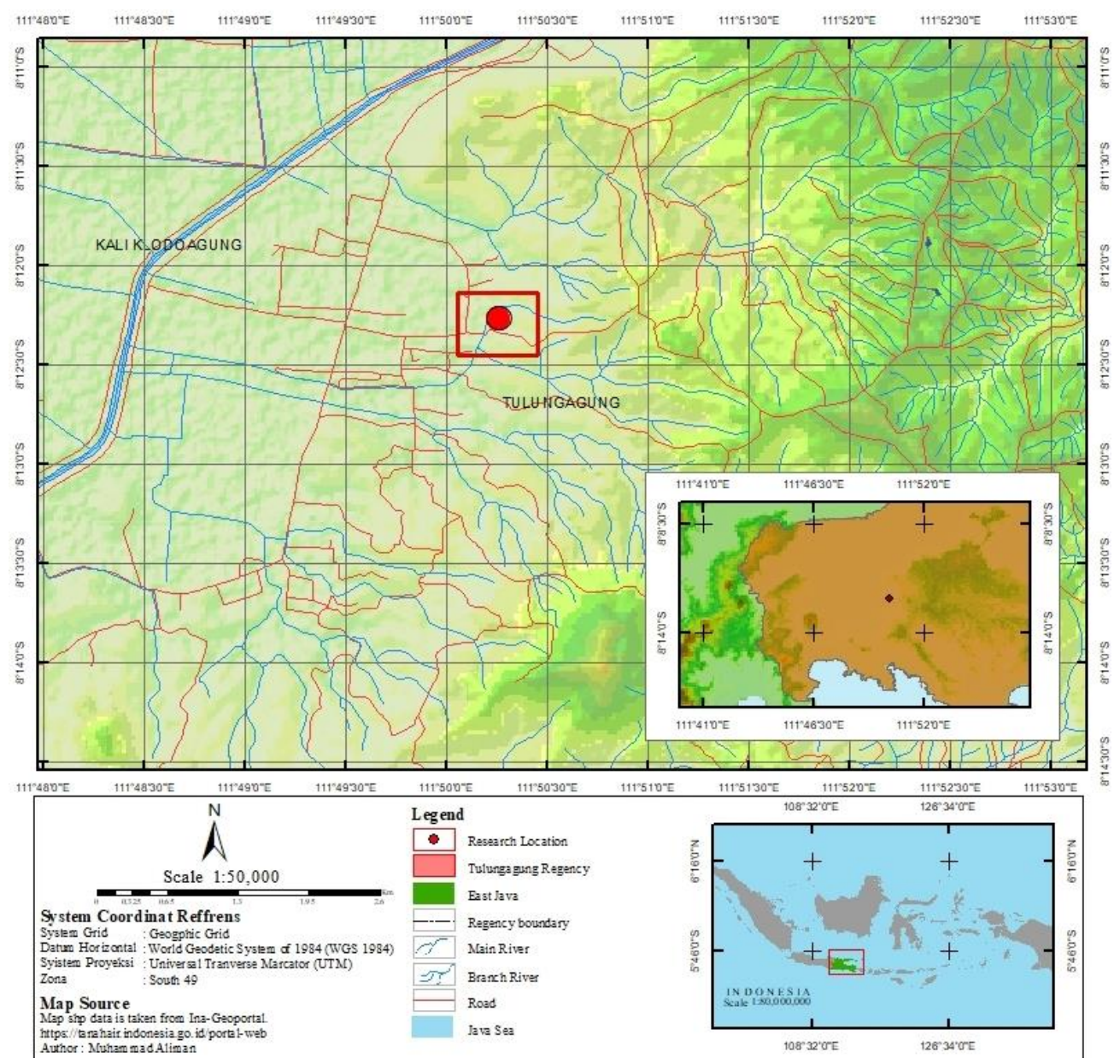

Figure 2. Map Lake Buret at East Java

\section{Data Collection Methods}

To collect the data, the following techniques were used: (1) observation, to find out the ecological and cultural conditions of the inhabitants being studied, and to find out about the lake management process. (2) In-depth interviews. (3) documentation studies to gather important information related to the subject and object of research (Creswell, 2012). The observations were made from the beginning of August to the end of August 2019, and in-depth interviews with selected informants were conducted from October to December 2019. The informants interviewed were Mr. KNS (Chair of the tourism awareness group also Chair of the Green Environment Group), Mr. ML (Buret Lake tourism manager), Ms. SM (village elder), Mr. MS (traditional leader) and Mr. AB (Geography teacher). The in-depth interview process with each informant was conducted separately. This technique was used to ensure data accuracy and avoid the influence of other informants. The interviews process was conducted for 2-3 hours or limited to the informants' knowledge in providing data related to the focus of this study. Some observation and interview activities are documented using a camera cellphone.

\section{Data Analysis}

To analyze research data, an interactive analysis model was chosen, which was developed by (Creswell, 2012). The analysis consisted of three stages, namely: (1) data reduction. At this stage, the researcher carried out the process of selecting, simplifying, abstracting and transforming rough data obtained from the field. (2) data presentation. The data presentation reduced was presented following the topic and subject matter, in order to facilitate the researcher to interpret the data. (3) conclusions. At this stage, the researcher verified or checked the truth of any data collected so that at the end of the research stage, the researcher was able to draw accurate conclusions based on the focus or problem of the research. Several criteria are used to ensure the validity of the data obtained during the research activities, namely: (1) the degree of trust, in order to fulfil this criterion, in-depth observation, triangulation and member-checking were carried out. (2) simplicity, in order to realize this criterion, the researcher tried to describe in detail, thoroughly, carefully and deeply during the subject matter under study, so that the data obtained with the data interpreted by the researcher can be distinguished (3) dependency, to meet the accuracy of the data, the researcher performed careful re-examination of the components, processes and results of research. (4) certainty, to meet this level of 
certainty, the researcher asked for help from fellow teachers who taught the students at SMAN I Campurdarat, which was located near the research location, in the form of peer discussion related to Buret Lake tourism management problems.

\section{RESULTS DISCUSSIONS}

\section{The Tourism Potential of Lake Buret}

Buret Lake is located in Sawo village, Campurdarat sub-district, Tulungagung Regency. It is located at an altitude between 200-500 meters above sea level and a latitude $8^{0} 12$ '27.30" and $111^{\circ} 50^{\prime} 12.65^{\prime \prime}$. This region has tropical rainy weather with AW type and average temperature of $24^{0}-27^{\circ} \mathrm{C}$. Average monthly rainfall of $122 \mathrm{~mm}$ and humidity of 74-77\%. The soil types are dark grey Alluvial brown with fine soil texture (Diskominfo, 2018). From city-center (Aloon-Aloon Tulungagung), the researcher needed to drive to the south to go to the location. By following the road, it helped the researcher to arrive at Campurdarat market. At the junction of Campurdarat market, the researcher took the left direction and continued to drive until the researcher arrived at Sawo Village. After that, there will be a T-junction, and the researcher turned right. The researcher followed the road until Buret Lake.

Buret Lake is one of the tourist attractions in Tulungagung Regency. It is located in Sawo Village, Campurdarat Sub-District, Tulungagung Regency, approximately $25 \mathrm{~km}$ from the center of Tulungagung City. Buret Lake area is approximately $400 \mathrm{~m} 2$. Even though it is quite small, this lake has its uniqueness. This lake is a water source that can flow through the four surrounding villages so that both in the rainy and dry seasons, the surrounding community can still plant rice throughout the year. These conditions are believed to last as long as the environmental conditions around the lake are maintained and sustainable. The fauna that can be found around the lake are monkeys (Macaca Mullata). These animals are not disturbed by the presence of visitors, so it can be concluded that there has been no hunting carried out by the local community on these animals. Therefore the number of this animal existence was considered significant. Also, various species of birds are found, including: sooty-headed Bulbul (kutilang) and long-tailed shrike (cendet). Sometimes, reptiles such as monitor lizards, lizards, and snakes are found around the lake. The existence of native fauna that lives in Lake Buret ecotourism can be an additional attraction for tourists. Nowadays, the attraction when visitors could interact with animals has increased. The visitors are very enthusiastic for sensations when interacting with wild animals such as feeding (Senigaglia et al., 2020).

\section{The Participation of the Green Environmental Group in Buret Lake Ecotourism Management}

Buret Environmental Conservation Park is located in Sawo Village, Campurdarat Sub-District, which functions to conserve water resources. The community that participates in water conservation is divided into two groups, namely the old group and the young group. Old group preserves this area by saving plants that are considered rare, fish that live in water sources and monkeys that are considered sacred. On the other hand, the young group preserves this area by planting trees around the area and on the mountain which is a water catchment area with a variety of rare plants. Existing plant species include: Ingas tree (this plant is considered sacred, if the sap touches human skin, it can cause a sensation like a burn), Samanea Saman/Rain Tree (Trembesi), Guava, Sengon, Flamboyan, Candlenut, and so on. This park is located on a limestone hill fault that extends east-west with a spring in the fault gap. The water from the Buret Water Source is used to irrigate rice fields in three villages. So far, Buret Lake has 179 types of plants which $70 \%$ of it was planned to make environmental tourism. Those plants include Gentong, Sole, Pucung, Beringin, Bendo, Kemaduh, Awar, Tuwingan, Gembilina, Rukem, and Ringin. The planting routine is carried out every year in January-March, to develop the original habitat here.

Buret area includes: Sawo village, Ngentrong village, Nggamping village, and Gedangan village. There are \pm 700 hectares of rice fields and Industrial areas. Long ago, the paddy field was harvested one time, but now it can be harvested three times. In 1995 - 2000 , the water commodity has dried. In 2015, the nature lover group received Kalpataru (Kalpataru is an award given to individuals or groups for their services in preserving the environment in Indonesia) from the president of Indonesia. In 2014, it received Kalpataru at the provincial level. The lake (KPS) is a local protected area. Ulur-ulur tradition is carried out for the preservation of the Buret Lake water source. Local wisdom (found in the lake) is catfish, bulus (soft-backed turtle), and bandher bang. Therefore, the role of local communities to manage ecotourism sustainability becomes essential to improve community welfare (Purnomo et al., 2020). Based on the results of interviews with local managers, it was known that the condition of the lake has indeed experienced positive changes compared to seventeen years ago which was very alarming. Precisely from 1998 to 2000, there has been massive deforestation by the community, and accordingly, it affected the condition of Buret Lake. Initially, Buret Lake was known as a center for animals such as sea turtles, bats and monkeys. Gradually, the animal began to disappear. It was compounded by the receding water conditions in the lake. Then the community's idea to improve the condition of the lake through reforestation and integrated management activities arised, as well as through local wisdom activities, namely the Ulur-Ulur. This activity was held once a year right on the Suro month on Legi Friday. Slowly at the end the condition of Buret Lake has returned to normal, and now it has been equipped with various facilities such as parking lots, toilets, play areas, and information offices. The procurement of ecotourism facilities provides the best service so that it has an impact on the high number of tourist visits (Purnomo et al., 2020).

Karsi Nero Sutamrin (Pioneer Youth of East Java), said that the principle is that if people are kind to nature, then nature will be kind to us too. "If you cut a tree you will feel guilty but if you plant a plant it will have many benefits and rewards from the plant." Karsi Nero Sutamrin: Chairperson of the tourism-awareness group and the green environmental group. Learning culture from a place could be so interesting. Though Buret Lake is still located in Tulungagung Regency, the slametan (communal feast) at Buret Lake is still preserved by the community. Some things that are found in the Buret Lake are a herd of monkeys and deer who welcome visitors near the entrance.

\section{The Potential of Ulur-Ulur Tradition as a Tourism Attraction in Buret Lake}

The existence of Buret Lake is closely related to the Ulur - ulur tradition as a form of gratitude of the people around the Buret Lake to the creator. The local traditions appear to human function as a creature of God and human function as guardians of the balance of nature (Wahyuningtyas et al., 2019). The following figure 3 shows a part of the process of Ulur-Ulur traditions.

The Ulur-Ulur tradition in Tulungagung is closely related to the existence of Lake Buret. Lake Buret is one of the central locations in this tradition. This lake is sourced from an underground river. Besides, there is a river that forms a flowing waterfall that fills the Buret Lake. Buret Lake is located in the limestone mountain. Therefore the existence of a water source in this region is indeed rare and need to be thankful. The water from the Buret Lake then channelled to the people's rice fields which cover four villages, namely, Sawo Village, Gedangan Village, Ngentrong Village and Gamping Village. Therefore, every year on Friday, in the Suro Lunar Month, the people hold the Ulur - Ulur Tradition. The Ulur-Ulur tradition is carried out to respect Eyang Jigang Joyo along with his daughter and son-in-law, Sri Rejeki and Sri Sedono (Asiyah, 2017). They are the characters behind the existence of Buret Lake, and they use the water to flow through the rice fields. Ulur- Ulur Tradition is done by decorating and bathing the statues of Dewi Sri and Joko Sedono. Then there is tayuban with the accompaniment of gending onang-onang, the procession of child carnivals holding rice, the Reog drums to flower sowing in Buret Lake. 
The best time to visit Burel Lake is in summer or when it is rarely raining. At this time, the water of Buret Lake is not muddy brown, and the tourists can enjoy the view of the lake water that is bluish-colored. Not only blue, sometimes the water looks emerald green. Its location in the Limestone Mountains does affect the color of this colorful lake. In the lake, there live several species of fish such as cork, sepat, and calf fish. The local community saves these fish so that the condition of the fish is still sustainable.
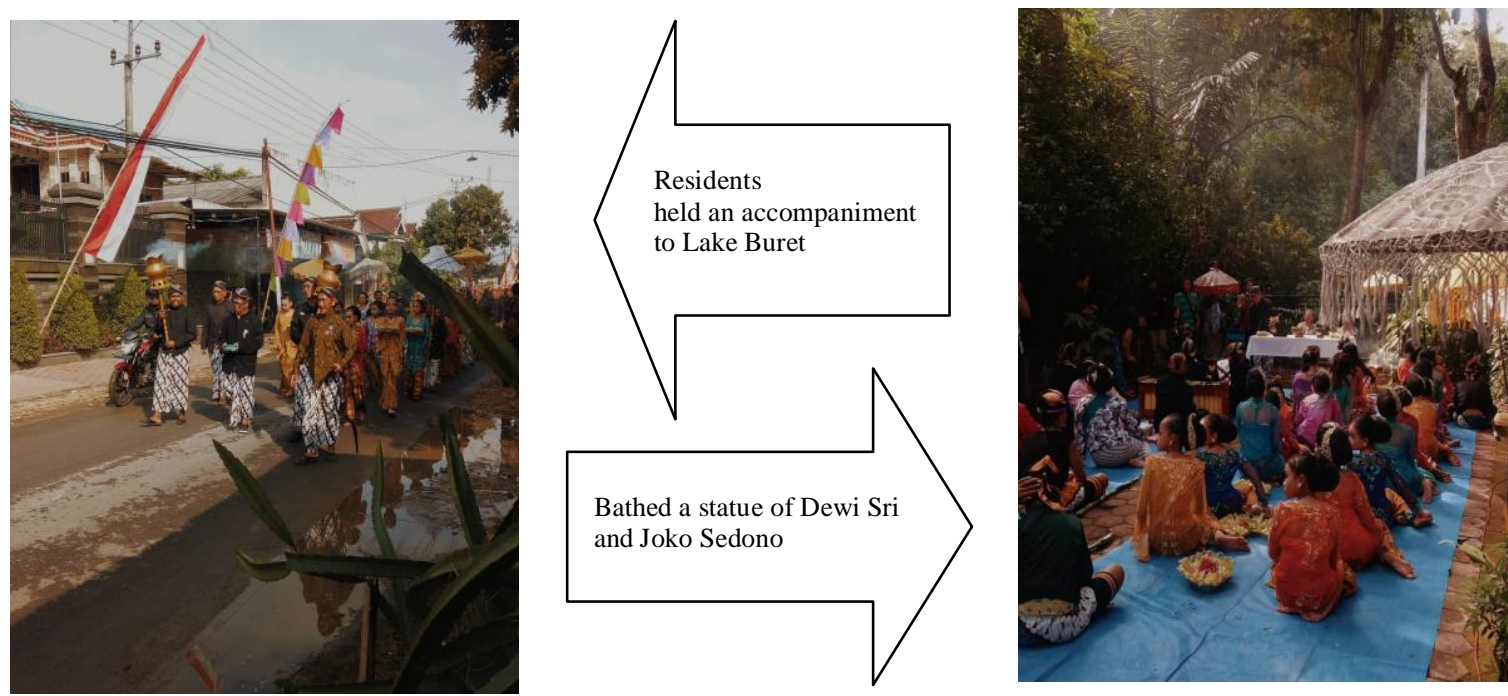

Figure 3. Ulur-ulur Traditions (Source: Primary Data, 2019)
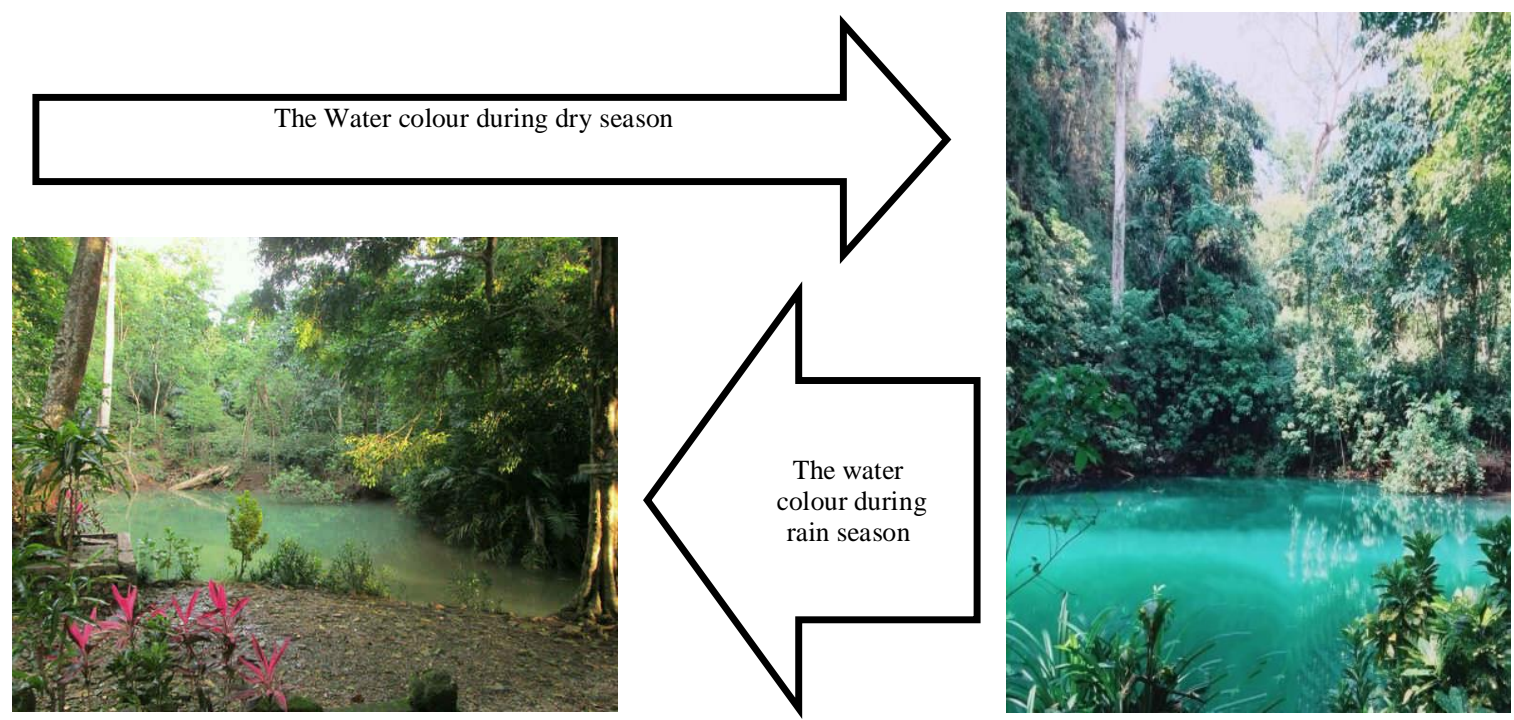

Figure 4. Water Condition in Buret Lake(Source: Primary Data, 2019)

The blessing that people felt from generation to generation is what makes the inhabitants always hold a thanksgiving ceremony called Ulur-ulur. This ceremony is carried out to pay homage to the ancestor named Eyang Jigang Joyo as well as his daughter and his son-in-law, Sri Rejeki and Sri Sedono. The three are believed to be the figures behind the existence of the Buret Lake. In this ceremony, various Javanese arts displayed, and the ceremony is ended with flower sowing into the lake. However, it is not just a ceremony. To keep Buret Lake water flowing, the communities of 4 villages also need to preserve the natural surroundings, including the prohibition of cutting down trees around the lake. The community also release various freshwater animals into the lake, as a means of conservation. Therefore, wild animals such as monkeys breed around lakes. The community from the Sendang Tirto Mulyo Group to guarantees the Buret Lake to remain sustainable. The respect for the three ancestors is carried out by not damaging the lake environment. That information about the Buret Lake that is considered sacred and full of the mystical background has provided many benefits for the surrounding population. Lake Buret and other various tourist attractions around it need an innovation to increase tourist visits (Farsani et al., 2011). The internet with applications can be used as one of the innovations to increased tourist visits to Lake Buret and can improve manager performances (Kurniawati and Ananda, 2019).

According to one of the local elders of the village, Sumini (96), Buret Lake has become the pulse of the life of the surrounding community. At least the villages of Sawo, Gedangan, Gamping and Ngentrong for the past one year have experienced the magic of this lake. Even though it is only small in size, the flowing water is never interrupted and continues to flow into the residents' rice fields. "I am also surprised how the water can continue to flow while the water is only this small," he said in Javanese. Even because the water source is so abundant, the 4 villages have never been connected to the primary irrigation channel owned by the government. Even without modern technical irrigation, rice fields can be planted up to 3 times a year. When other villages suffer from drought and water shortages, the communities of the 4 villages never feel worried, thanks to the existence of the Buret Lake (Surya, 2012).

Ulur-ulur is a traditional ceremony carried out by the people of Buret Hamlet, Sawo Village, Campurdarat Sub-District, Tulungagung Regency. This ceremony is a form of thanks or gratitude, because such a small lake is able to irrigate the rice fields of four villages. Such as Sawo Village, Besole Village, Gamping Village. Mbah Sami, a village elder who has been preparing the Ulur-ulur ceremony for 15 years 
said that each ceremony must prepare offerings and it should be made by people from the four villages. These offerings will be cok bakal, market snacks, ripih, Lodho rice, and others. After the prayers are read, then all the food is distributed to those present, and a small portion is given to the animals in the lake. The animals are various types of fish, bulus, and monkeys. Feeding can be used as one of the tourist attractions by tourists. This feeding activity does not disrupt the animal's natural diet. However, continuous feeding by tourists can disrupt the natural diet of animals (Senigaglia et al., 2020). All those involved in the offering ceremony are expected to taste the food. The leader of the ritual also offerings researcher who is near, "Sir, whether you like it or not, please taste this food just a little, as a form of respect for the people of this lake". The Ulur-ulur ritual is begun by a variety of processions from the house of the local village head towards Buret Lake. At this location, all offerings are placed right next to Mbah Joyo's grave, right on the edge of Buret Lake. The mantras will be recited while burning incense, above the tomb of Mbah Joyo. After praying, the core leader of ritual will bath two statues of men and women. According to the ritual leader, the two statues are the embodiment of Sri Rejeki and Sri Sedono, son-in-law and daughter of Mbah Joyo. Ritual is centered on respecting the ancestors, as well as the motherland who has given a living. Ulur-ulur is part of local wisdom. Because of respect for the ancestors, residents keep the lake area still filled with trees and wild animals. The ritual ends with the distribution of cakes and banana offerings. It is the moment awaited by inhabitants, as well as anyone who attends the ritual because there is a belief that whoever eats cakes or banana offerings, then the sincere desire of his/her heart will be granted (Cahyono, 2013).

When performing the ceremony, a procession is carried out. The ceremony entourage departs from the preparation site. At the front are the food cages (Jodang) amounted to 4 pieces, each is sent from the four villages. Jodang is shouldered by two people in front and behind. Behind Jodang are spear carriers and bowls filled with incense that had been lit. Next is a pair of brides who carry "bride and groom" clothing equipment, followed by several beautiful girls carrying a colorful flower basket to be sown in the lake. The next row is elders from the local village and regency, as well as the leader of the traditional ceremony. Then in the last row is a group singing the blessing song (sholawat) with the tambourine. It looks sacred but also unique. Sacred because it is carried out in such a way which is full of mystical background and unique because it is carried out unusually, which is there are people with complete Javanese dress carry the offerings in the front row, but there is also the group (sholawat) at the very back row. It turned out to be on purpose. Kasepuhan (the elderlies) as manager and savior of the Buret Lake environment was once opposed by the surrounding community. Their activities were considered contrary to Islamic teachings. Finally, public figures from various religions are invited. It is done in order to get all elements involved in environmental conservation efforts. Thus, such traditional ceremonies are carried out in such a unique and sacred way.

\section{CONCLUSION}

From the results of research and discussion above, it can be concluded that: Buret Lake tourism is very beautiful and it is also a unique karst area which the water source can continuously irrigate the inhabitants' fields in the four villages. The participation of the green environmental group and the community participation is essential in managing tourist attractions and conserving the Buret Lake. The preservation of the Ulur-ulur ceremonial procession in every year strongly supports the management of the Buret Lake tourism. The procession of Ulur-Ulur ceremonies preserved by the community indirectly conserves the natural environment of Lake Buret. The ceremonial attractions of Ulur-ulur, the diversity of flora and fauna are an integrated tour package for visitors. Also, the community can provide accommodation for tourists by providing food stalls, the outbound attractions, lodging and other facilities. Excellent facilities and services have an impact on increasing the number of visits to improve the welfare of the community. This study recommends that tourism managers, both government, private and community, could integrate local traditions because they are an important part of the sustainable ecotourism. In addition to providing new job opportunities, involving local communities in ecotourism management can maintain local traditions that contain the noble values of their predecessors.

\section{Aknowlegments}

Thank you to all the communities around the Buret Lake area, Campur Darat District, Tulungagung Regency, Indonesia. Also, all the leaders of the Faculty of Social Sciences, State University of Malang. This research does not contain a conflict of interest or any intention towards individuals or group.

\section{REFERENCES}

Adji, T. N. (2010). Condition of the Gunungsewu Karst Underground River catchment area and its environmental impact on Water Resources (Hydrological) due to human activities. Seminar on the Conservation of Groundwater Resources in the Gunung Kidul Karts Region, Yogyakarta.

Arifin, E. F. R. (2018). Song Bajul Spring Potency for Resident's Clean Water Supply in Pucanglaban Village, Tulungagung in 2017-2032. IOP Conference Series: Earth and Environmental Science, 145, 012140. https://doi.org/10.1088/1755-1315/145/1/012140.

Asiyah, N. (2017). Tulungagung Legend Story (Study of Structuralism Claude Levi Strauss). Bapala, 4(1).

Blatnik, M., Culver, D.C., Gabrovšek, F., Knez, M., Kogovšek, B., Kogovšek, J., Liu, H., Mayaud, C., Mihevc, A., \& Mulec, J. (2020). Lithomorphogenesis of Karst Surface. In Karstology in the Classical Karst (pp. 33-98). Springer.

Cahyono, A.S. (2013). Regional Autonomy to Build Nation Leader Character Based on Local Culture to Maintain the Integrity of the Republic of Indonesia. Jurnal Bonorowo, 1(1), 72-87.

Creswell, J.W. (2012). Qualitative Inquiry and Research Design: Choosing Among Five Approaches. SAGE Publications. https://books.google. co.id/books?id $=$ OJYEbDtkxq8C.

Diskominfo. (2018). Tulungagung Regency General Data and Statistics in 2018. Tulungagung District Communication and Information Office. https://tulungagung.go.id/wp-content/uploads/2019/01/Data-dan-Statistik-Umum-2018.pdf .

Dwyer, L. (2015). Globalization of tourism: Drivers and outcomes. Tourism Recreation Research, 40(3), 326-339.

Fang, W.-T. (2020). Sustainable Tourism. In W.-T. Fang (Ed.), Tourism in Emerging Economies: The Way We Green, Sustainable, and Healthy (pp. 209237). Springer. https://doi.org/10.1007/978-981-15-2463-9_9.

Farsani, N.T., Coelho, C., \& Costa, C. (2011). Geotourism and geoparks as novel strategies for socio-economic development in rural areas. International Journal of Tourism Research, 13(1), 68-81. https://doi.org/10.1002/jtr.800.

Fatin, A.N. (2020). The identification of Aquifer in the karst area of Humala village in Wakatobi Regency with a Combination of the Geoelectric Method of Wenner-Schlumberger Configuration and Vertical Electrical Sounding (Ves). Jurnal Rekayasa Geofisika Indonesia, 1(03), 17-24.

Firdaus, F., Shalihin, N., Anggreta, D. K., Yasin, F., \& Tutri, R. (2019). Improving the Benefits of Karamba Into Tourism Activities: An Effort to Reduce the Ecological Impact of Aquaculture in Maninjau Lake, Indonesia. GeoJournal of Tourism and Geosites, 26(3), 726-736. https://doi.org/10.30892/gtg.26304-392.

Garidzirai, R., \& Pasara, M.T. (2020). An Analysis of the Contribution of Tourism on Economic Growth in South African Provinces: A Panel Analysis. GeoJournal of Tourism and Geosites, 29(2), 554-564. https://doi.org/10.30892/gtg.29214-489.

Gasper, D., Shah, A., \& Tankha, S. (2019). The framing of sustainable consumption and production in SDG 12. Global Policy, $10,83-95$. 
Huo, Y., \& Wang, Y. (2020). High-Quality Development of Tourism Industry Under the Trend of Cultural and Tourism Integration Based on Big Data Analysis. In Z. Xu, R.M. Parizi, M. Hammoudeh, \& O. Loyola-González (Eds.), Cyber Security Intelligence and Analytics (pp. 479-486). Springer International Publishing. https://doi.org/10.1007/978-3-030-43306-2_68.

Istiawati, N. F., Susilo, S., Budijanto, Nyoman Ruja, I., \& Widodo, S. (2020). Construction of Krui Community Knowledge on Repong Damar Culture in Lampung's West Coast. IOP Conference Series: Earth and Environmental Science, 412, 012005. https://doi.org/10.1088/1755-1315/412/1/012005.

Joa, B., Winkel, G., \& Primmer, E. (2018). The unknown known - A review of local ecological knowledge in relation to forest biodiversity conservation. Land Use Policy, 79, 520-530. https://doi.org/10.1016/j.landusepol.2018.09.001.

Kiper, T. (2013). Role of ecotourism in sustainable development. InTech.

Kurniawati, E., \& Ananda, K.S. (2019). The decision taken by the SME Kopi Malam Jumat (Friday Night Coffee) towards improving their culture by adopting E-Commerce as a vehicle towards Internationalisation. Tourism and Leisure, 11.

Laksamana, E.E. (2005). Stasiun Nol Teknik-teknik Pemetaan Goa dan Survey Hidrologi Goa. Megalith Books Bekerjasama dengan Acintyacunyata Speleologi Club.

Lestawi, I.N., \& Bunga, D. (2020). The Role of Customary Law in the Forest Preservation in Bali. Journal of Landscape Ecology, 13(1), 25-41. https://doi.org/10.2478/jlecol-2020-0002.

Mutia, T., Bachri, S., Astina, I. K., \& Aliman, M. (2019). Local wisdom in Indonesia's customary forest management: Case studies in Sasak, Bali Aga and Minangkabau. Ecology Environment Conservation, 25(3), 7

Nella, A., \& Christou, E. (2016). Extending tourism marketing: Implications for targeting the senior tourists'segment.

Poudyal, N. C., Watkins, C., \& Joshi, O. (2020). Economic contribution of wildlife management areas to local and state economies. Human Dimensions of Wildlife, 0(0), 1-5. https://doi.org/10.1080/10871209.2020.1716114.

Purnomo, A., Idris, I., \& Kurniawan, B. (2020). Understanding Local Community in Managing Sustainable Tourism at Baluran National Park-Indonesia. GeoJournal of Tourism and Geosites, 29(2), 508-520. https://doi.org/10.30892/gtg.29210-485.

Putri, I.H.N., Sholihah, U., Handayani, E.M., \& Sumarmi, S. (2018). The Development of Digital Teaching Material Supplements in Geography Subjects on Marine Resources Topics Based on Local Wisdom. Jurnal Pendidikan Geografi: Kajian, Teori, dan Praktek dalam Bidang Pendidikan dan Ilmu Geografi, 23(2), 78-84.

Senigaglia, V., New, L., \& Hughes, M. (2020). Close encounters of the dolphin kind: Contrasting tourist support for feeding based interactions with concern for dolphin welfare. Tourism Management, 77, 104007. https://doi.org/10.1016/j.tourman.2019.104007.

Sumarmi. (2018). The Local Genius of Tengger People in Conserving Forest and Increasing Economic Benefits Using Agroforestry System. IOP Conference Series: Earth and Environmental Science, 145(1), 012135. https://doi.org/10.1088/1755-1315/145/1/012135.

Suri, H. (2011). Purposeful sampling in qualitative research synthesis. Qualitative Research Journal, 11(2), 63.

Surya. (2012). Keajaiban Telaga Buret Hidupi Empat Desa. https://surabaya.tribunnews.com/2012/09/21/keajaiban-telaga-buret-hidupi-empat-desa.

Von Hirschheydt, G., Kindvall, O., \& de Jong, J. (2020). Testing bat abundance and diversity predictions by PREBAT, a connectivity-based habitat suitability model for insectivorous bats. European Journal of Wildlife Research, 66(2), 1-14.

Wahyuningtyas, N., Tanjung, A., Idris, I., \& Dewi, K. (2019). Disaster Mitigation on Cultural Tourism in Lombok, Indonesia. GeoJournal of Tourism and Geosites, 27(4), 1227-1235. https://doi.org/10.30892/gtg.27409-428. 